\title{
NEW APPROACHES TO THE ANALYSIS OF POPULATION TRENDS \\ IN LAND BIRDS
}

\author{
Frances C. James \\ Department of Biological Science \\ Florida State University \\ Tallahassee, Florida 32306-2043, USA
}

\author{
Charles E. McCulloch \\ Biometrics Unit, 337 Warren Hall \\ Cornell University \\ Ithaca, New York 14853, USA
}

David A. Wiedenfeld

Museum of Natural Science

Louisiana State University

Baton Rouge, Louisiana 70803, USA

BU-1276-M

February, 1995 


\section{Abstract}

Although there is strong evidence that a few Neotropical migrant land birds have severely declining populations, we know of no evidence of general overall declines. One widely cited analysis of data from the Breeding Bird Survey (BBS), the only continental-scale monitoring program for land birds in the breeding season, indicates declining populations in eastern forests in the $1980^{\prime} \mathrm{s}$, but other analyses conclude that most species have had stable or increasing populations in the last 25 years. These conflicting results suggest that a new perspective is called for. Here, we propose two approaches to the analysis of BBS data that emphasize the detection of temporal and geographic variation in population trends. The first approach uses nonlinear regression to detect temporal changes in population trends and permits the construction of graphs that compare nonlinear trends among regions. The second approach provides statistical tests of multispecies patterns of geographic variation in population trends.

We report analyses of BBS data for 1966 to 1992 for the 26 species of wood warblers (Parulinae) for which the most data are available and the chance of obtaining reliable estimates is best. Using pooled data for all 26 species for eastern and central North America, nonlinear regression indicated declining populations in the Appalachian Mountains and the Eastern Foothills in the 1970's and stability elsewhere. As examples of the use of this first approach in single-species analyses, we give maps, graphs, and statistical tests to illustrate variation in population trends by physiographic strata in the Blue-winged Warbler (Vermivora pinus) and the Ovenbird (Seiurus aurocapillus). As an example of the second approach, 
we applied a probit-normal model to a matrix of increases and decreases in the 26 species in 37 geographic strata. The analysis identified specific highland areas as having unusually high proportions of declining populations. These results suggest that correlates of elevation should be considered as factors possibly regulating populations of warblers and other land birds. Our perspective is that focus on studies of temporal and geographic variation in population trends of all birds, including Neotropical migrants, could help conservation biologists identify where species and groups of species are in the most trouble.

Key words: Neotropical migrants, population trends, nonlinear regression, North American Breeding Bird Survey, National Biological Survey

Key phrases: 


\section{Introduction}

A major theme in avian conservation biology in the United States is that populations of Neotropical migrant birds (those that breed in North America and winter in Central and South America or the Caribbean) are generally declining (Terborgh 1989). There are numerous reasons to expect such declines, but the evidence of recent overall declines in Neotropical migrants is, in fact, inconclusive. Declining numbers of migrant species on long-term study plots like Breeding Bird Censuses (Butcher et al. 1993) may not be representative of changes across the larger geographic areas (Hutto 1988, Finch 1991).

The only continental-scale survey that provides baseline data about the status of North American land birds from the mid-1960's to the present is the Breeding Bird Survey (BBS) (Erskine 1978, Robbins et al. 1986, Droege and Sauer 1990, Erskine et al. 1992, Peterjohn et al. in press). Robbins et al. (1989), on the basis of an analysis of Breeding Bird Survey (BBS) data, estimated major increases in populations of Neotropical migrants that breed in eastern forests in the 1970's and decreases from those rates in the $1980^{\prime} \mathrm{s}$, a difference often cited as predictive of longterm trends. But the most recent analysis of BBS data by the National Biological Survey indicates that 58 of approximately 100 species have had increasing populations in the last 25 years (Sauer et al. 1994), close to the 508 that would be expected if population sizes were fluctuating randomly around stable values. Reviews of the literature on the status of Neotropical migrants usually conclude that the evidence for overall declines is conflicting but that the potential for disaster is so great that giving priority status to Neotropical migrants is justified (e.g., 
Askins et al. 1990, Finch 1991, Askins 1993). Even so, authors of popular articles who warn of massive declines (Morton and Greenberg 1989, Wilcove 1990, Line 1993) are subject to what Askins et al. (1990) call the "Chicken Little syndrome."

What should be the next step in research to identify conservation priorities? With regard to land birds that are adequately sampled by the BBS, including Neotropical migrants, we think it should be to emphasize comparisons of population trends among areas (see Hunter et al. 1993) and to look for multispecies patterns. Such comparisons are useful, even for species like the Cerulean Warbler (Dendroica cerulea) (Villard and Maurer this Special Feature), for which there is strong evidence of widespread and prolonged declines (Robbins et al. 1992), because they can identify places where rates of decline are the highest. In this paper we offer some examples of this approach, based on exploratory analyses of the BBS database at the level of the physiographic stratum. First we summarize overall trends in the BBS data for 26 species of wood warblers (Parulinae). Then, for the Blue-winged Warbler (Vermivora pinus) and the Ovenbird (Seiurus aurocapillus), we show how a combination of maps, graphs, and statistical tests can indicate the major features of geographic and temporal variation in a population trend. Finally, we give an example of a multispecies analysis that allows the identification of strata where an unusual proportion of species' populations have been decreasing (hotspots of decline). Such patterns of covariation across species can be used to generate hypotheses about causes of population declines that affect more than one species. This general approach to causal analysis looks at many places and sets up many comparisons (James and McCulloch in press). 
Methods

Our analysis is based on data for 1966 to 1992 for 922 BBS routes in eastern and central North America (Fig. 1), organized into 8 regions and 37 physiographic strata (Table 1), according to a slight modification of Bailey's ecoregions (Bailey 1980, 1983, Bailey and Cushwa 1981; see also Robbins et al. 1986). The full details of criteria for selection of routes for analysis, regression methods, calculation of confidence limits and hypothesis tests, construction of graphs and maps, and application of the probit-normal model are presented in the Appendix.

Breeding Bird Survey data are noisy in that they contain sources of variation other than changes in the sizes of the populations of birds. Some of the variation is due to variation in weather, time of day, and differences between observers in their ability to detect birds. We gained some control over the first two variables by selecting only routes censused under the best conditions. To assure that each route provides reliable information about population trends, our criteria for the selection of routes are conservative. To be included in the analysis, each route had to have been run at least eight times and at least once in each fifth of the 25 -year BBS period.

We prefer to use nonlinear regression methods of analysis rather than linear methods (see, e.g., Geissler and Noon 1981, Geissler and Sauer 1990, Sauer and Droege 1990), because nonlinear methods do not require choosing a model a priori (Taub 1990). We use two different methods, nonlinear nonparametric route regression (NNRR, James et al. 1990, 1992) and nonlinear semiparametric route regression (NSRR), both of which use LOESS (Cleveland and Devlin 1988) as a technique to fit a smooth nonlinear curve. 
The difference between the methods is that NSRR includes an adjustment for the fact that differences among observers in their ability to detect birds may have changed during the BBS period (Sauer et al. 1994). We present the results of both methods so that the reader can see that there is a tradeoff between the advantages of controlling for potential observer effects and the loss in precision attributable to adding the observer variable to the model. Paired maps for single species are designed to display geographic variation in recent abundance among physiographic strata and changes in abundance since early in the BBS period. An important feature of these maps is that changes are expressed in categories of change that are balanced between increases and decreases, allowing the reader to judge changes in a balanced way.

In any model, incorporating additive observer effects comes at a significant cost in decreased precision. As a result, with NSRR, when observer covariables are in the model, estimates for years near the limits of the available years can be even more unreliable than with smoothing only. After examining the magnitude of this source of variation, we found that the most stable estimates of population trends were those obtained four years from the ends of the time series. Therefore, our tests (Tables 1 and 2) compare the average of the 1986-1988 smoothed estimates to the 1970-1972 estimates. Under NSRR, observer effects are removed before this difference is estimated. This estimate of trend was chosen to be comparable to a linear trend estimate. If a straight-line model is fit, the slope estimate is proportional to the difference in smoothed estimates. As the smoothing parameter ( $\underline{f}$ ) in NNRR and NSRR is increased, more of the data are used to calculate each smoothed estimate. The results then become 
closer to straight-line models, and linear and nonlinear approaches become equivalent. The use of nonlinear regression does not preclude performing statistical tests on trend estimates based on criteria such as differences between early and late periods, but one trade-off with performing such tests is that, because they require reducing estimates of trends to single numbers, some information is lost. The flexibility allowed by the choice of the smoothing parameter is an advantage in exploratory data analysis.

To discover whether there has been geographic variation in multispecies population trends, we created a table of the 26 species by the 37 strata and filled the cells with $1^{\prime}$ s and $0^{\prime}$ s. A 1 represented an estimated decline (no matter how small) for the period 1970-1972 to 1986-1988, and a 0 represented an estimated increase (no matter how sma11). Again, results are presented with both NNRR and NSRR. To analyze such data, one must incorporate correlations among species within a stratum. Because the data are binary, an extension of a binary-data model (e.g. a probit model) is needed that allows for correlated data. We used a probit-normal model (McCulloch 1994; see also the Appendix) with random stratum effects and fixed species effects.

We performed a test for variation among stratum effects and estimated best-predicted values of the stratum effects. If there were no geographic differences in population trends among strata, all the stratum effects would be zero, and a hypothetical average species would have the same probability of decrease for each stratum, equal to the overall probability of decrease across strata. In the presence of stratum effects, favorable strata will have a lower than average probability that an average species will decrease, and unfavorable strata will have a higher than average 
probability of decrease. Reports of these estimated high probabilities of decrease for a hypothetical, average species have two advantages over direct reports of the observed proportions of declining species. First, a formal statistical test of equality of stratum effects can be performed after differences in species composition are accounted for. Thus, a stratum is not declared unfavorable merely because it contains a collection of species that are declining uniformly across strata. Second, the test accounts for differences in the number of species among strata and assigns less weight to strata with few species.

\section{$\underline{\text { Results }}$}

\section{Overall Trends in Warblers by Region}

For the 26 most abundant species of warblers in eastern and central North America (Table 2), as analyzed with NSRR, the largest estimated total populations in recent years $(1986-1988)$ have been in four regions, the Spruce-Hardwood and Boreal Forest, the Appalachian Mountains, the Eastern Foothills, and the Eastern Coastal Plain (Table 1). Graphs of the overall population trends with all species combined (Fig. 2) suggest that the total number of warblers decreased slightly in the 1970's (Fig. 2a) and that this decrease occurred mainly in the Appalachian Mountains and the Eastern Foothills (Fig. 2b). There is no evidence of decreases in the total numbers of individual warblers in the Spruce-Hardwood and Boreal Forest or in the Eastern Coastal Plain. Thus, the overall 68 decline estimated to have occurred between 1970-1972 and 1986-1988 (see the end of Table 1, last column) seems to have occurred mainly in two regions and mainly in the $1970^{\prime} \mathrm{s}$. 
Overall Population Trends in Warblers by Species. Habitat, and Period

When the 26 species of warblers are ordered by their overall estimates of population change, with the most extreme declines at the top of the list (Table 2), the first six species on the 1ist are the Cerulean, Prairie, and Canada Warblers (Dendroica cerulea, D. discolor, D. canadensis), the Yellow-breasted Chat (Icteria virens), the Golden-winged Warbler (Vermivora chrysoptera), and the American Redstart (Setophaga ruticilla), all of which merit special conservation attention. Only the top four are statistically significant by both methods. At the other end of the list are at least eight species that are estimated with both NNRR and NSRR to have increased substantially, although not all estimates are statistically significant by both methods. The median percent change for the 26 -species sample is estimated to be a $16 \%$ increase with NNRR and a $2 \%$ increase with NSRR. Under neither method does a predominance of declining species breed in forest or woodland habitat or in open, successional, or scrub habitat (end of Table 2). To allow comparisons with other analyses (Robbins et al. 1989, Peterjohn et al. in press), we divided the period in half. The percent of species increasing between early (1970-1972 and 1978-1980) and recent (1978-1980 and 1986-1988) periods with NSRR was 548 for the early and $58 \%$ for the recent period, a small difference that did not seem to merit a statistical test. In spite of some major differences between the two regression methods in estimates for individual species, the general picture is that a few species may be in serious trouble but that most are not. Whether NSRR estimates are more reliable than the NNRR estimates is unknown. Our graphs are based on NSRR results because Sauer et al. (1994) 
think that improvements over the BBS period in the ability of BBS observers to detect birds is a source of substantial bias in the data.

The most abundant species of warblers for the physiographic strata where they occur are Common Yellowthroat (Geothlypis trichas), Ovenbird (Seiurus aurocapillus), Yellow-breasted Chat (Icteria virens), Chestnut-sided Warbler (Dendroica pensylvanica), and Nashville Warbler (Vermivora ruficapilla) (Table 2, columns 3 and 4). Differences in overall trends show, for example, that the chat population is estimated to have declined significantly and that the Ovenbird population has increased significantly during the BBS period. However, such comparisons do not reveal where in the geographic ranges any of the declines and increases are occurring. Even for the Ovenbird, a management program might be helpful in some parts of its geographic range. The major trends in the temporal and regional population dynamics of a species can be understood only by study of the combination of the statistical tests, maps, and graphs.

Geographic and Temporal Variation in Population Trends by Species a. The Blue-winged Warbler

On the basis of data for 208 routes in 12 strata (Table 2), the Blue-winged Warbler is estimated to have increased more than any of the other 26 species in our sample (618 and 388 between 1970-1972 and 1986-1988 with NNRR and NSRR respectively). The species is most abundant in the stratum Southern New England and Glaciated Coastal Plain (14), where the recent increase has been most pronounced (compare Fig. 3a, b). Note also declines in the southern part of its geographic range (Ohio Hills, 17, and Northern Piedmont, 9). Its northerly-advancing population in the Great Lakes Plain and the Driftless Area (23 and 24, Fig. 3a) has not increased 
in magnitude enough to appear as a major change in Fig. 3b. Striking additional information about this species that was not revealed by the statistical tests or the maps appears in the graph (Fig. 4), where the decline in the Ohio Hills is shown to have occurred only in the $1980^{\prime} s$. The geographic range of the Blue-winged Warbler has been expanding northward, but at the same time populations have been declining at the southern edge of the breeding range.

b. The Ovenbird

On the basis of BBS data from 422 routes in 20 strata, the Ovenbird population is estimated to have increased substantially during the period analyzed (298 and 188 estimated increases between 1970-1972 and 1986-1988 with NNRR and NSRR respectively; both figures are statistically significant by a $z$-test). Its geographic pattern of recent abundance (Fig. 5a) shows it to be most abundant in the Adirondack Mountains, Northern New England, and the Spruce-Hardwood and Boreal Forest (strata 19-21) and common in several adjacent areas and in the Cumberland Plateau (16). In spite of general increases in Ovenbird populations throughout most parts of its range, the analysis indicates substantial declines in Ovenbirds in the Blue Ridge Mountains (15), the Adirondack Mountains (19) and the Ozark Plateau and Ouachita Mountains (13) (Fig. Sb). Graphs that allow comparisons among nonlinear trends for the Ovenbird (Fig. 6a, b) show that the general increases have been strongest in Northern New England (20) and the Great Lakes Transition (25) in the 1980's. The declines in the Adirondacks occurred in the 1970's, but those in the Blue Ridge Mountains continued into the 1980's. 
Geographic Variation in Multispecies Population Trends: The ProbitNormal Model

Calculations of the percent of species declining by strata (column 3 in Table 1) can suggest strata where exceptionally high proportions occur. For example, for strata with an average of more than five species, the strata with the highest estimated proportions of declining species are the Cumberland Plateau (858), Adirondack Mountains ( 808$)$, and the Blue Ridge Mountains (758) and the declines of individual warblers in these strata were a significant 438 and 288 in the first two strata and an nonsignificant 498 in the Blue Ridge Mountains, which had only 4 routes that met our criteria for inclusion in the analysis (Table 1). However, these calculations, even with their statistical tests, can be misleading. Could the significant declines in the numbers of individual warblers in the Cumberland Plateau and Adirondack Mountains still be due to the small number of routes in the analysis for these strata? The application of the probit-normal model to a matrix of increases and decreases by species and strata provides a formal overall test of this possibility and indicates that indeed there is statistically significant overall geographic variation in population trends ( $\underline{P}<0.01$ with both NNRR and NSRR). In a particularly poor stratum (i.e., one with a high proportion of declining species), such as the Cumberland Plateau, the estimated probability of decrease based on NNRR is 0.76 , compared to 0.50 for a neutral stratum; in a particularly good one, that is, one with a low proportion of declining species, like the St. Lawrence River Plain, the probability of decrease is 0.20 rather than 0.50 (Table 4). With NNRR, the probability of decline for an average species was greater than 0.7 in four strata in the Southern Appalachians 
and in the Ouachita Mountains (Table 4a, Fig. 7). With NSRR, the Adirondack Mountains, as well as the Cumberland Plateau and Blue Ridge Mountains, met this criterion (Table 4a, Fig. 8).

The most significantly declining and increasing species showed their most extreme trends in the highland strata. For example, with NSRR the stratum with the largest percent declines in Canada Warblers was the Adirondack Mountains; the one with the largest decreases in Cerulean and Prairie Warblers was the Cumberland Plateau; the one with the largest percent decline in the Prairie Warbler was the Blue Ridge Mountains; and the one with the largest percent decline in the Cerulean Warbler was the Ouachita Mountains. The Mourning Warbler increased in all strata except the Adirondacks. The Magnolia Warbler, which was also significantly increasing overall, had its highest increase in the Adirondacks. These estimates suggest that dynamic changes have been taking place in breeding bird populations in highland areas.

The probit-normal model also identified strata with high proportions of increasing species. With NNRR, the probability of decline for an average species was less than 0.3 (i.e., probability of an increase was greater than 0.7 ) in an area from New England and the southern sections of the maritime provinces of Canada westward through the Great Lakes Plain and prairie provinces of Canada (Table 3b, Fig. 7). With NSRR only the St. Lawrence River Plain met this criterion (Table 3b, Fig. 8).

\section{Discussion}

\section{Declines in Highland Areas and Causes}

Here we analyzed data for all 26 species of warblers in eastern and central North America for which we think that reliable estimates can be 
made. Western North America was excluded because there are far fewer data for that area. In addition to the estimates of unusual declines in highland areas in the southern Appalachians (see also James et al. 1990), NSRR has indicated that unusual declines have occurred in warblers in the Adirondack Mountains. No published analyses of BBS data have indicated generally declining bird populations west of the Great Plains, but clearly the issue of possible elevational effects should be checked there. Our conclusion that elevation is a correlate of declines in warblers in eastern and central North America must still be considered tentative. Even our statistical tests can be subject to error due to undetected biases in the data. However, in another study, we used NNRR to estimate population trends for 65 species including Neotropical migrants, partially Neotropical migrants, temperate zone migrants, and resident species (unpublished report by wiedenfeld et al. 1992). That report identified three of the Appalachian strata mentioned above (Adirondack Mountains, Cumberland Plateau, and Blue Ridge Mountains) as areas with high proportions of declining species of all types. Thus we think that the declines reported in the present study are not just a property of warblers or of Neotropical migrants, but of all groups of breeding land birds.

One possible causative factor of declines in upland areas is atmospheric pollution (see review by Graveland 1990), a known correlate of elevation in the eastern U.S. (Lindberg et al. 1988, Shriner et al. 1990). Atmospheric pollution can affect the growth of trees directly and can indirectly affect caterpillar and other arthropod populations, the main food of songbirds in the summer (van Noordwijk 1990). Also, atmospheric pollution can reduce the availability of minerals in the vegetation and 
soil. Female songbirds need extra calcium at the time of egg-laying. Graveland et al. (1994) have shown experimentally that, in the Great Tit (Parus major), clutch size, egg-shell thickness, and fledging success rates are calcium-limited in areas of the Netherlands where atmospheric pollution has reduced the availability of calcium to the birds. Similar work would be required (see Mahoney 1994) to establish such a causal relationship in North America.

Elsewhere we explore the possibility of analyzing causes of population trends by making comparisons among strata based on quasiexperimental designs (James et al. in press). See also Bohning-Gaese et al. (1992) for an analysis based on BBS data that explores causes. Clearly, the sorting out of potential causes should involve analytical sampling (Eberhardt and Thomas 1991). Ideally, studies should combine censuses in areas that have different levels of environmental factors with data on reproductive success and survival of marked birds in these areas.

\section{Methodological Issues}

We found that the median trend for all 26 species of warblers is lower with NSRR (28) than with NNRR (168). This difference may be due to the inclusion of observer effects in NSRR, but the trade-off in precision involved with adding observer effects to the model would necessitate more analysis to establish this conclusion. We do not know why we do not see the same differences between early and recent periods in the percentages of species declining that have been reported by the National Biological Survey (NBS) (Peterjohn et al. in press). Another question is why the identification of the Canada Warbler as a species in serious decline both in our analyses and in that of the Canadian Wildlife Service (Erskine et 
al. 1992) was not detected by the NBS (Sauer and Droege 1992, Peterjohn et al. in press). The answers must be either in the differences in how the routes were selected, how the data were handled, or possibly both. Nonparametric regression methods (such as NNRR and NSRR) estimate a regression curve without making strong assumptions about the shape of the true regression function (Altman 1992). The methods are used here to estimate population trends in terms of counts of birds per route for routes on which the species occurred ( $t$ - and $z$-tests, maps) and nonlinear trends in density by strata (graphs). Because of the smoothing procedure, LOESS estimates of three-year averages $(1970-1972,1986-1988)$ are determined from all the data, not just data for those years. The NBS (Peterjohn et al. In press) tests the statistical significance of population trends in BBS data as whether the slope of a linear regression on a log scale is different from zero. Nonparametric tests can also be appropriate for testing the statistical significance of trends in environmental data (Hirsch et al. 1982, Berryman et al. 1988).

\section{Comparisons with Other Studies}

A recent summary of BBS data from the FWS, which is for 1966-1991 (Peterjohn et al. in press), reports that the overall percentage of declining species of Neotropical migrants, including warblers, was higher in the recent half of the $B B S$ period than in the earlier half, as did Robbins et al. (1989). However, the estimated percentage of Neotropical migrants declining was 308 in the first half of the period and 548 in the second half; for warblers, the percentage declining was 228 in the first half of the period and 568 in the second half. Thus, in the NBS analysis, it is the high proportion of increasing populations before 1979 ( 708 of all 
Neotropical migrants and 788 of all warblers increasing) rather than the approximately half declining since 1979 that seems to demand explanation. NBS estimates of 548 of Neotropical migrants and 568 of all warblers decreasing in the recent period are close to the null hypothesis of $50 z$ and thus do not represent alarming values. Independent analyses by the Canadian Wildlife Service based on a modification of LRR have indicated more significant increases than decreases in Neotropical migrants in the BBS period in Canada (Collins and Wendt, 1989; Erskine et a1., 1992).

Recent analyses of BBS data by the U.S. Fish and Wildlife Service and other sources indicate that groups other than Neotropical migrants are in substantially more trouble than are Neotropical migrants. Examples are grassland-nesting species (Knopf in press), permanent residents and short-distance migrants (Sauer et al. 1994), wading birds in some areas, some waterfowl, and some shorebirds (Howe et al., 1989). With a broader perspective (Askins 1993) that explores geographic variation in population trends in combination with nonlinear analyses, we suspect that new conservation priorities will be identified.

Summary and Recommendations

1. Our analyses for the period 1966 to 1992 indicate that only a few of the 26 most common species of wood warblers have had rapidly declining populations in eastern and central North America. The overall proportion of species with decreasing trends is not higher than that with increasing trends, nor do we see a change toward decreasing trends of warblers between the first and second halves of the BBS period, as reported by the NBS.

The issue of generally declining populations of Neotropical migrant land birds has been subject to such a degree of overgeneralization that, 
unless the situation is clarified, we risk undermining the credibility of avian conservation programs. For species for which the BBS data are appropriate, we recommend detalled studies of population trends in all species, regardless of their migratory status. If they are feasible, we recommend comparisons of the rates of reproduction and survival of marked birds (see Sherry and Holmes 1993) in areas with different trends and different environmental conditions, then direct management toward those ecological processes that are driving population trends. If, for example, Ovenbird populations are declining in the Appalachian Mountains because of ecosystem-level damage caused by atmospheric deposition, local manipulations of habitat features will not solve the problem.

2. We estimate that some species of warblers that are doing well elsewhere in eastern and central North America have had declining populations in highland areas. Several species with the most dramatically declining populations overall had their extreme decreases in these areas. Research that compares the breeding biology of all birds in these physiographic strata with populations of the same species in other environments is called for. The application of the probit normal model allows formal statistical tests of these multispecies patterns.

3. We recommend using nonlinear nonparametric route regression (NNRR) and nonlinear semiparametric route regression (NSRR) for the analys is of BBS data. These methods involve minimal assumptions about the form of the curve of population size through time and produce results that can be used to test the statistical significance of population trends. NSRR allows observer covariables to be included in the model. A particular advantage of the nonlinear regression method is that it allows visual comparisons of 
nonlinear patterns of population change through time among geographic areas. When the results are restricted to just increases and decreases, statistical tests are feasible and maps are useful for making comparisons among different areas within the geographic range of a species. Direct comparisons between these and other methods of selecting and analyzing trends in BBS data are needed. 
Acknowledgments

We thank Lyla Messick for preparing the maps; Duncan Evered and Julia Smith for discussions; Bruce Peterjohn, John Sauer, and Sam Droege for helpful comments and provision of the data; and Christopher Davison, Barry Noon, Robert Selander, Daniel Simberloff, Leonard Thomas, and Walter Tschinkel for reviews of drafts of the manuscript. 


\section{Literature cited}

Altman, N. S. 1992. An introduction to kernel and nearest-neighbor nonparametric regression. The American Statistician 46:175-185.

Aptech Systems. 1992. GAUSS Reference manual Ver 2.1. Kent, Washington.

Askins, R. A. 1993. Population trends in grassland, shrubland, and forest birds in eastern North America. Pages 1-34 in D. M. Power, editor. Current ornithology, vol. 11. Plenum Press, New York.

Askins, R. A., J. F. Lynch, and R. Greenberg. 1990. Population declines in migratory birds in eastern North America. Pp. 1-57 in D. M. Power (ed.), Current Ornithology, Vol. 7. Plenum Press, New York.

Bailey, R. G. 1980. Description of the ecoregions of the United States. U.S. Department of Agriculture, Misc. Publ. 1391. Washington, D.C. Bailey, R. G. 1983. Delineation of ecosystem regions. Environmental Management 7(4):365-373.

Bailey, R. G., and C. T. Cushwa. 1981. Ecoregions of North America. U.S. Fish and Wildlife Service FWS/OBS-81/29, Washington, D.C. 1 map sheet and text.

Berryman, D., B. Babée, D. Cluis, and J. Haemmerli. 1988. Nonparametric tests for trend detection in water quality time series. Water Resources Bulletin 24:545-556.

Bohning-Gaese, K., M. L. Taper, and J. H. Brown. 1992. Are declines in North American insectivorous songbirds due to causes on the breeding range? Conservation Biology 7:76-86. 
Butcher, G. S., B. Peterjohn, and C. J. Ralph. 1993. Overview of bird population monitoring programs and databases. Pages 192-203 in D. M. Finch and P. W. Stangel, editors. Status and management of Neotropical migratory birds. USDA, Rocky Mountain Forest and Range Experiment Station, Ft. Collins, Colorado.

Cleveland, W. S. 1979. Robust locally-weighted regression and smoothing scatterplots. Journal of the American Statistical Association $74: 829-836$.

Cleveland, W. S., and S. J. Devlín. 1988. Locally weighted regression: an approach to regression analysis by local fitting. Journal of the American Statistical Association 83:597-610.

Collins, B. T., and J. S. Wendt. 1989. Technical report 75: The Breeding Bird Survey in Canada, 1966-1983: analysis of trends in breeding bird populations. Canadian Wildlife Service, Ottawa, Ontario.

Droege, S., and J. R. Sauer. 1990. North American Breeding Bird Survey annual summary 1989. U.S. Fish Wildl. Serv., Biol. Rep. 90:1-22.

Eberhardt, L. L., and J. M. Thomas. 1991. Designing environmental field studies. Ecological Monographs 61:53-73.

Erskine, A. J. 1978. The first ten years of the cooperative breeding bird study in Canada. Can. Wildl. Serv. Rep. Ser. 41:1-61.

Erskine, A. J., B. T. Collins, E. Hayakawa, and C. Downes. 1992. The cooperative Breeding Bird Survey in Canada, 1989-1991. Canadian Wildlife Service, Progress Notes 199.

Finch, D. M. 1991. Population ecology, habitat requirements, and conservation of Neotropical migratory birds. U.S.D.A. Forest Service, Gen. Tech. Report RM-205. 
Finney, D. J. 1964. Statistical methods in biological assay, 2nd edition. Griffen, London.

Geissler, P. H., and B. R. Noon. 1981. Estimates of avian population trends from the North American Breeding Bird Survey. Pp. 42-51 in C. J. Ralph and J. M. Scott, editors. Estimating the numbers of terrestrial birds, Stud. Avian Biol. 6.

Geissler, P. H., and J. R. Sauer. 1990. Topics in route regression analysis. Pp. 54-57 in J. R. Sauer and S. Droege, editors. Survey designs and statistical methods for the estimation of avian population trends. U.S. Fish and Wildlife Serv., Biol Rep 90(1).

Graveland, J. 1990. Effects of acid precipitation on reproduction in birds. Experientia 46:962-970.

Graveland, J., R. van der Wal, J. H. van Balen, and A. J. van Noordwijk. 1994. Poor reproduction in forest passerines from decline of snail abundance on acidified soils. Nature 368:446-448.

Hastie, T. J., and R. J. Tibshirani. 1990. Generalized additive models. Chapman and Hall, London.

Hirsch, R. M., J. R. Slack, and R. A. Smith. 1982. Techniques of trend analysis for monthly water quality data. Water Resources Research $18: 107-121$.

Howe, M. A., P. H. Geissler, and B. A. Harrington. 1989. Population trends of North American shorebirds based on the International Shorebird Survey. Biological Conservation 49:185-199. 
Hunter, W. C., D. N. Pashley, and R. E. F. Escano. 1993. Neotropical migratory landbird species and their habitats of special concern within the southeast region. Pages 159-169 in D. M. Finch and P. W. Stangel, editors. Status and management of Neotropical migratory birds; 1992 September 21-25, Estes Park, Colo. Gen. Tech. Rep. RM229. U.S. Department of Agriculture, Forest Service, Rocky Mountain Forest and Range Experiment Station, Ft. Collins, Colo.

Hutto, R. L. 1988. Is tropical deforestation responsible for the reported declines in Neotropical migrant populations? American Birds $42: 375-379$.

James, F. C., and C. E. McCulloch. Quasiexperimental design and setting priorities in the program for Neotropical migratory birds. In press in T. E. Margin and D. M. Finch, editors. Ecology and management of Neotropical migratory birds: a synthesis and review of critical issues. Oxford University Press, Oxford, England.

James, F. C., C. E. McCulloch, and L. E. Wolfe. 1990. Methodological issues in the estimation of trends in bird populations with an example: the Pine Warbler. Pages 84-97 in J. R. Sauer and S. Droege, editors. Survey designs and statistical methods for the estimation of avian population trends. U.S. Fish and Wildlife Service, Biological Report $90(1)$.

James, F. C., D. A. Wiedenfeld, and C. E. McCulloch. 1992. Trends in breeding populations of warblers: declines in the southern highlands and increases in the lowlands. Pages 43-56 in J. M. Hagan III and D. W. Johnston, editors. Ecology and conservation of Neotropical migrant landbirds. Smithsonian Institution Press, Washington, D.C. 
James, F. C., C. E. McCulloch, and J. Cox. Quasiexperimental design and setting priorities in the program for Neotropical migratory birds. In press in T. E. Martin and D. M. Finch, editors. Ecology and management of Neotropical migratory birds: a synthesis and review of the critical issues. Oxford University Press.

Knopf, F. Avian assemblages on altered grasslands. Studies in Avian Biology, in press.

Lindberg, S. E., D. Silsbee, D. A. Schaefer, J. G. Owens, and W. Petty. 1988. A comparison of atmospheric exposure conditions at high and low elevation forests in the southern Appalachian Mountains. Pages 321 344 in M. Unsworth, editor. Processes of acidic deposition in mountainous terrain. Kluwer Academic Publishers, London.

Line, L. 1993. Silence of the songbirds. National Geographic Magazine, June, pages $68-90$.

Mahoney, N. A. 1994. A comparison of the breeding success of Black-capped Chickadees and Chestnut-sided Warblers in healthy and declining sugar maple forests in central Ontario. M.S. thesis, Trent University, Peterborough, Ontario, Canada.

McCulloch, C. E. 1994. Maximum likelihood variance components estimation for binary data. Journal of the American Statistical Association $89: 330-335$.

Morton, E. S., and R. Greenberg. 1989. The outlook for migratory songbirds. "Future shock" for birders. American Birds 43:178-183. 
Peterjohn, B. G., J. R. Sauer, and C. S. Robbins. The North American breeding bird survey and population trends of Neotropical migrant birds. In press in T. E. Martin and D. M. Finch, editors. Ecology and management of Neotropical migratory birds: a synthesis and review of the critical issues. Oxford University Press.

Robbins, C. S., D. Bystrak, and P. H. Geissler. 1986. The Breeding Bird Survey: its first fifteen years, 1965-1979. U.S. Fish and wildlife Service Resource Publication 157:1-196. Washington, D.C.

Robbins, C. S., J. R. Sauer, R. S. Greenberg, and S. Droege. 1989. Population declines in North American birds that migrate to the Neotropics. Proceedings of the National Academy of Sciences of the USA $86: 7658-7662$.

Robbins, C. S., J. W. Fitzpatrick, and P. B. Hamel. 1992. A warbler in trouble: Dendroica cerulea. Pages 549-562 in J. M. Hagan III and D. W. Johnson, editors. Ecology and conservation of Neotropical migrant landbirds. Smithsonian Institution Press, Washington, D.C.

Sauer, J. R., and S. Droege. 1990. Survey designs and statistical methods for the estimation of avian population trends. U.S. Fish and Wildl. Serv., Biol. Rep. $90(1)$.

Sauer, J. R., and S. Droege. 1992. Geographic patterns in population trends in Neotropical migrants in North America. Pages 26-42 in J. M. Hagan III and D. W. Johnston, editors. Ecology and conservation of Neotropical migrant landbirds. Smithsonian Institution Press, Washington, D.C.

Sauer, J. R., B. G. Peterjohn, and W. A. Link. 1994. Observer differences in the North American Breeding Bird Survey. The Auk 111:50-62. 
Searle, S. R., G. Casella, and C. E. McCulloch. 1992. Variance components. Wiley, New York.

Sherry, T. W., and R. T. Holmes. 1993. Are populations of Neotropical migrant bird limited in summer or winter? Implications for management. Pages 47-57 in D. M. Finch and P. W. Stangel, editors. Status and management of Neotropical migratory birds. USDA, Rocky Mountain Forest and Range Experiment Station, Ft. Collins, Co.

Shriner, D. S., W. W. Heck, S. B. McLaughlin, D. W. Johnson, P. M. Irving, J. D. Joslin, and C. E. Peterson. 1990. Response of vegetation to atmospheric deposition and air pollution. NAPAPP SOS/T Report 18 . In Acidic deposition: state of science and technology, volume III. National Acid Precipitation Assessment Program, Washington, D.C. Taub, S. R. 1990. Smoothed scatterplot analysis of long-term Breeding Bird Census data. Pages 80-83 in J. R. Sauer and S. Droege, editors. Survey designs and statistical methods for the estimation of avian population trends. U.S. Fish and Wildlife Service, Biological Report $90(1)$.

Terborgh, J. W. 1989. Where have all the birds gone? Essays on the Biology and Conservation of Birds that Migrate to the American Tropics. Princeton University Press, Princeton, New Jersey. van Noordwijk, A. J. 1990. The effects of forest damage on caterpillars and their effect on the breeding biology of the Great Tit, an overview. Pages 215-222 in J. Blondel, A. Gosler, J.-D. Lebreton, and R. McCleery, editors. Population biology of passerine birds, an integrated approach. Springer-Verlag, Berlin. 
Wiedenfeld, D. A., L. R. Messick, and F. J. James. 1992. Population trends in 65 species of North American birds, 1966-1990. Final Report to the National Fish and Wildlife Foundation, Washington, D.C.

Wilcove, D. 1990. Empty skies. Populations of many species of songbirds are declining dramatically, and deforestation ranks highest on the list of reasons. The Natural Conservancy Magazine 40:4-13. 
APPENDIX - -STATISTICAL METHODS

1. SELECTION OF ROUTES AND ROUTE YEARS, AGGREGATION OF ROUTES

In the present analysis, we used only the best quality data (Type 1 as designated by the NBS). Routes were used only if they (1) had been run at least eight times and (2) had been run at least once in each of the five periods $1966-1972,1973-1975,1976-1980,1981-1983$, and 1984-1992. This procedure assured that only routes that had been fairly consistently run throughout the time period of the BBS were included. It eliminated routes run only sporadically, routes run early in the BBS period but later discontinued, and routes begun only recently. In practice, the above criteria meant that most routes selected had been run very regularly and many more than eight times. Only a few routes met the criteria minimally. One route-year is one route run one time, as routes are only run once each year.

For each species separately:

a. Select strata to be included. Strata were eliminated from the analysis for a species if the species had been recorded on fewer than five routes in the stratum or on fewer than 58 of the total route-years in the stratum. This criterion eliminated strata in which the species did not usually occur but in which it had been recorded occasionally, for example, during migration. It also eliminated some strata where the species did occur consistently but in low numbers, usually at the periphery of its range.

b. Transform. Because all data are counts, and therefore non-normally distributed, we transformed them by taking the square root of each value. Using the square-root transform has the advantage that all zeroes remain zero and all ones remain one, and it is not necessary to add a constant to the data before transformation, as is necessary with $\log$ transformations. 
c. Smooth each route separately. Examination of a sample of routes suggested that the best value for moderate smoothing by the smoothing parameter ( $f$, see below) most frequently fell around $f=0.50$. We have therefore used $f=0.50$ for all of the smoothing at the route level.

d. Aggregate routes into strata. For each year separately, we averaged the smoothed values for all routes in a stratum. When applied to all strata, this procedure aggregated the routes into a set of as many series as there were strata in the analysis.

e. Smooth the stratum series. The aggregate series for each stratum was smoothed again, using $f=0.25$. The choice of $f$ value should be made on the basis of the desired level of sensitivity to short-term changes (James et al. 1990).

f. Aggregate strata. To form estimates of aggregations of strata, weight them proportionally to their area. As in step d, for each year separately, we averaged the weighted stratum values, aggregating the stratum curves to produce an overall series.

\section{REGRESSION METHODS}

The two methods, nonlinear nonparametric route regression (NNRR) and nonlinear semiparametric route regression (NSRR), both make use of the nonlinear smoothing technique, LOESS, developed by Cleveland (1979) and Cleveland and Devlin (1988, and references therein). We used LOESS to model counts as a smooth function of year, i.e.,

$$
Y_{i j}=g\left(t_{j}\right)+\epsilon_{i j},
$$

where $Y_{i j}$ is the transformed count for route $i$ in year $t_{j}$ and $\epsilon_{i j}$ represents error. LOESS is useful for the purpose of description and can be used to detect and demonstrate peaks, troughs, or plateaus, not just straight-line trends. Use of LOESS requires choice of a smoothing parameter, $f$, which 
gives the proportion of the data used in calculating the smoothed value at a single time. This flexibility in choice is one of the advantages of its application.

NNRR and NSRR differ only in that NSRR includes an additive observer effect in the model. Observers differ, and if there has been any consistent change in observer abilities, the change in observer abilities would bias the results. The model for NSRR is thus

$$
Y_{i j}=g\left(t_{j}\right)+o_{i(j)}+\epsilon_{i j},
$$

where $Y_{i j}, g\left(t_{j}\right)$, and $\epsilon_{i j}$ are as in (A1) and $O_{i(j)}$ is the effect of the observer for year $t_{j}$ on route $i$. The NSRR smoothed counts were estimated from the following algorithm (Hastie and Tibshirani, 1990). Let $x$ be the full rank observer-effect matrix as in a regular multiple linear regression of count on time, incorporating observer covariables as dummy variables. Let $Y$ be the vector of transformed counts. Calculate

$$
\begin{aligned}
& \text { 1. } \mathrm{X}_{\mathrm{Sm}}=\text { LOESS smoothed columns of } \mathrm{X} \\
& \text { 2. } \mathrm{Y}_{\mathrm{Sm}}=\text { LOESS smoothed columns of } \mathrm{Y} \\
& \text { 3. } \mathrm{X}_{\text {res }}=\mathrm{X}-\mathrm{X}_{\mathrm{Sm}} \\
& \text { 4. } \mathrm{Y}_{\text {res }}=\mathrm{Y}-\mathrm{Y}_{\mathrm{Sm}} \\
& \text { 5. } \hat{\beta}=\left(\mathrm{X}^{\prime} \mathrm{X}_{\text {res }}\right)^{-1} \mathrm{X}^{\prime} \mathrm{Y}_{\text {res }}
\end{aligned}
$$

Then the smoothed trend was estimated by smoothing $Y-X \hat{\beta}$ using LOESS. All other details of NNRR and NSRR remained the same.

3. Calculation of Statistical tests

The paired t-tests used to determine the significance of differences between the beginning and ending values of a series were calculated in the following way:

a. Use the data produced by step c, above (smoothed routes). 
b. Calculate paired differences. For each route, subtract the average for the three years 1970-1972 from the average of the three years 1986-1988. The result is a single value for each route, here called $\Delta$.

c. The weighted mean $\Delta$ (weighted as in step $f$, above) divided by its standard error (SE) is distributed approximately according to a normal distribution (z). That is

$($ mean $\Delta) / S E=z$

The probability of $z$ values can be obtained from a table that gives probabilities of the normal distribution.

d. Variances and confidence intervals can be calculated for LOESS values by year using route-to route variability within strata (James et al. 1990, Table 3). The estimated variance of the mean for the ith stratum is $s_{i}{ }^{2} / n_{i}$, where $n_{i}$ is the number of routes in a stratum. To get the variance for a weighted average of strata, calculate $\Sigma w_{i}{ }^{2}\left(s_{i}{ }^{2} / n_{i}\right)$, where $w_{i}$ is the area weight for the $i_{\text {th }}$ mean. For approximate confidence intervals, use $\pm 2 \sqrt{ }$ var.

e. A disadvantage to performing statistical tests is that they require reducing estimates of trends to single numbers.

4. GRAPHS AND MAPS

The graphs present nonlinear trends as patterns of change across years in smoothed estimates of birds per route. The values by stratum are indices to the density of the species in the entire stratum because routes with zero counts for that species are averaged in. For statistical tests of differences in population size between early and late periods and for plotting such differences on maps, we use estimated values for the average number of birds per route, calculated for routes on which the species occurred in at least some years. This type of trend is not the same as one 
based on estimates of density, so the maps and tests present a different aspect of population change than do the graphs.

5. PROBIT-NORMAL MODEL

The probit-normal model is a generalization of the probit model (Finney 1964) and is used for including random effects in a probit model to allow for correlations. The model is as follows:

$Y_{i} \sim$ Bernoulli $\left(p_{i}\right)$, conditional on the random effects, $u$,

$P_{i}=\Phi\left(x^{\prime}{ }_{i} \beta+z^{\prime}{ }_{i} u\right)$,

where $\Phi(\cdot)$ is the standard normal cumulative distribution function, and $x_{1}$ are the independent (fixed-factor) variables associated with the ith observation, the $u^{\prime} s$ are the random effects, and $z_{i}$ is the $i$ th row of the matrix indicating the correspondence between the ith observation and the random effects. The u's are assumed to be normally distributed with mean zero and variance-covariance matrix $D$. For fitting the two-way data matrix of species by stratum we defined

$$
Y_{i j}= \begin{cases}1 & \text { if there was an increase for species } i \text { in stratum } i \\ 0 & \text { otherwise }\end{cases}
$$

and we use the model

$$
\begin{aligned}
P_{i j} & =P\left(\text { increase for } Y_{i j}\right) \\
& =\Phi\left(\mu_{i}+s_{j}\right)
\end{aligned}
$$

where $\mu_{i}$ are the (fixed) species effects and $s_{j}$ are the (random) stratum effects. The $s_{j}$ are assumed to be normally distributed with zero mean and variance $\sigma^{2}$. We calculated the estimates of the parameters $\left(\mu_{i}, \sigma^{2}\right)$ by numerically maximizing the likelihood using programs written in the language GAUSS (Aptech Systems, 1992). Predicted values for the $s_{j}$ were calculated by estimating the best predicted values (Searle et al. 1992). The probit normal 
model can be applied to any matrix of increasing and decreasing species by strata. 
Table 1. Thirty-seven physiographic strata in eight regions, showing the number of routes in the analysis, the average number of species and individual warblers recorded recently estimated with NSRR, the percent of species declining, and the percent change in the numbex of individual warblers. Asterisks in the last column denote statistical significance at $\alpha-<0.05$ based on $t$-tests for the strata and a $z$-test for the estimate of the overall percent change in the number of Individual warblers.

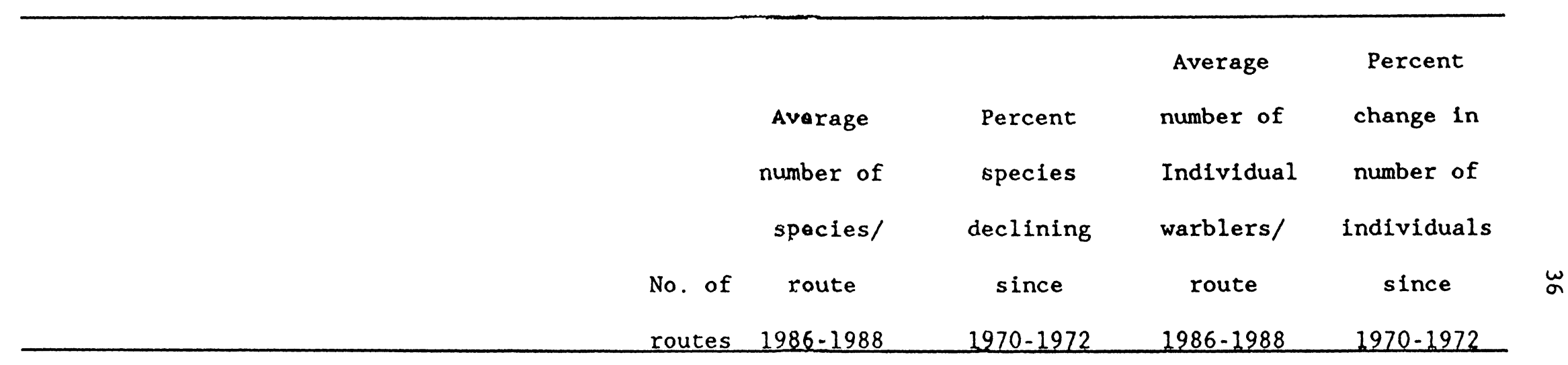

Eastern Coastal Plain and Mississippi

Embayment

$\begin{array}{lrrrrr}\text { 1. Floridian } & 9 & 3 & 67 & 10 & 3 \\ \text { 2. Coastal Flatwoods } & 23 & 8 & 25 & 21 & -2 \\ \text { 3. Coastal Prairies } & 10 & 2 & 0 & 3 & 81 \\ \text { 4. Mississippi Alluvial Plain } & 13 & 9 & 67 & 14 & -45 \\ \text { 5. Eastern Texas Prairies } & 16 & 1 & 0 & <1 & >100 \\ \text { 6. S. Upper Coastal Plain } & 69 & 14 & 43 & 23 & -9\end{array}$


Table 1 (continued).

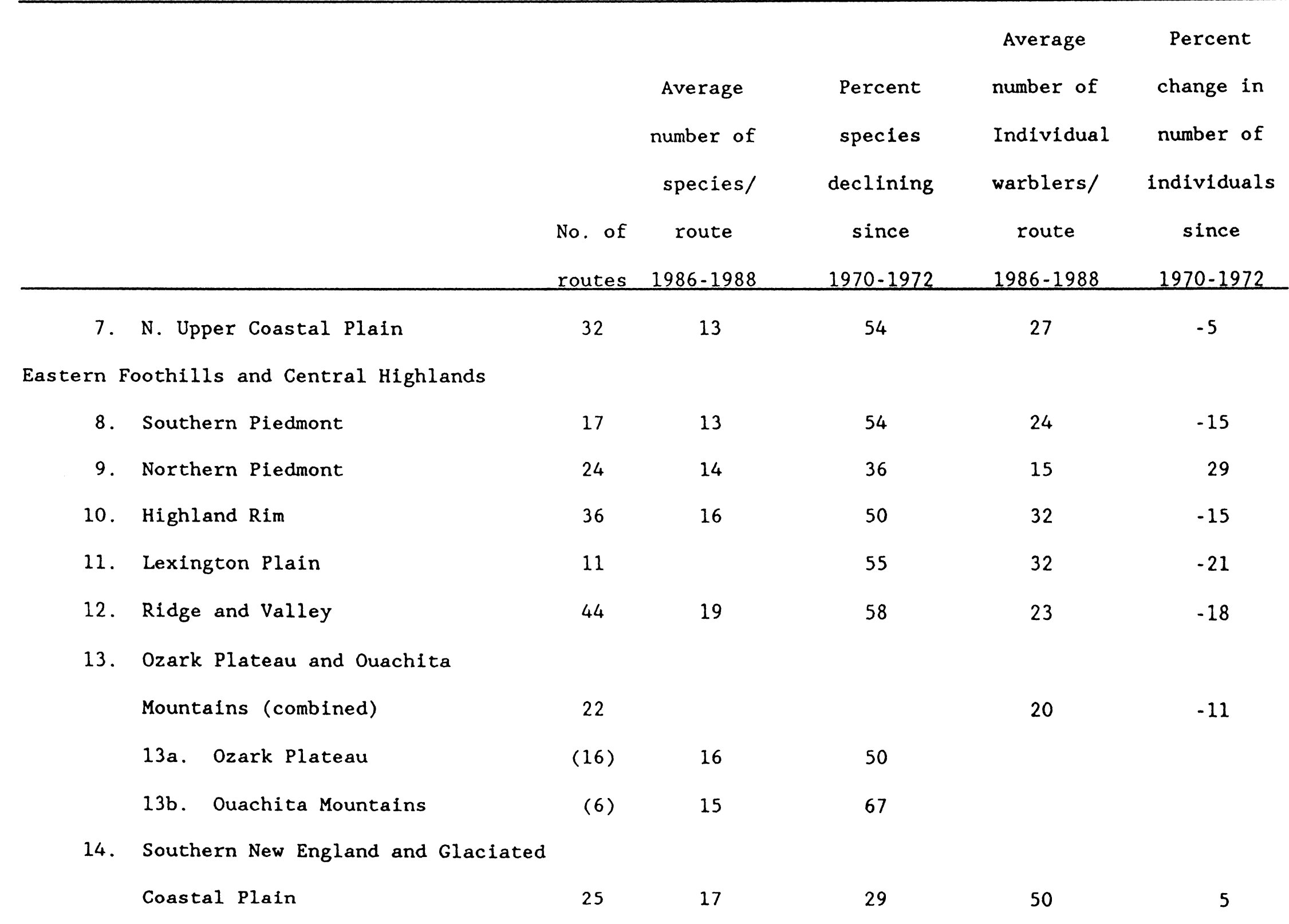


Table 1 (continued).

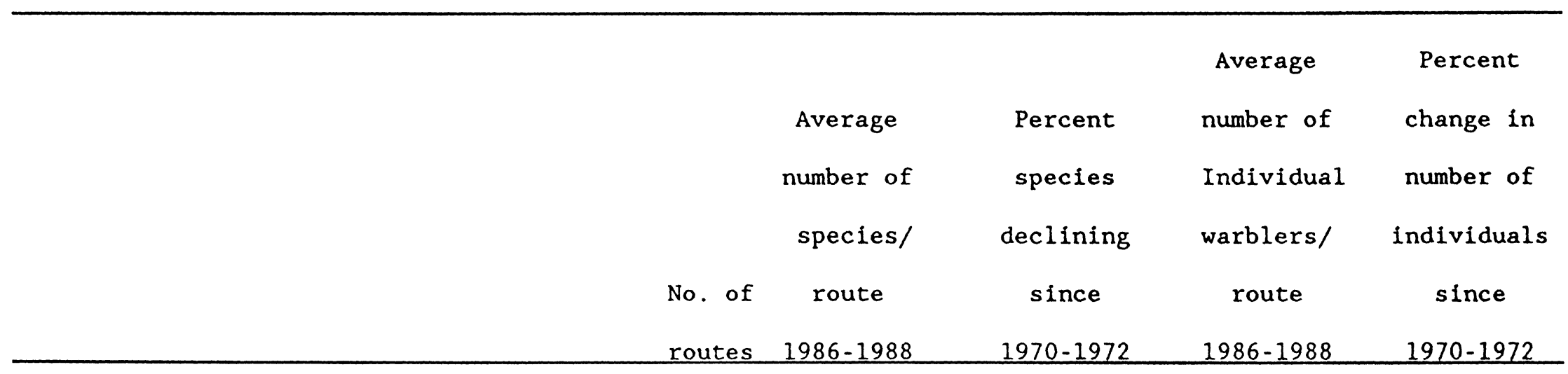

Appalachian Mountains
15. Blue Ridge Mountains
16. Cumberland Plateau
17. Ohio Hills
18. Allegheny Plateau
19. Adirondack Mountains
20. Northern New England

Spruce-Hardwood and Boreal Forest

21. Spruce-Hardwood and Boreal Forest

Great Lakes Plains
22. St. Lawrence River Plain

23. Great Lakes Plain

$\begin{array}{rr}4 & 16 \\ 6 & 18 \\ 21 & 15 \\ 45 & 24 \\ 8 & 15 \\ 22 & 17\end{array}$

75
85
47
33
80
59

37

69

41

50

74

70

38

13

25
$-49$

$-43 *$

$-18$

$20 *$

$-28 *$

$-4$

1

42*

53* 
Table 1 (continued).

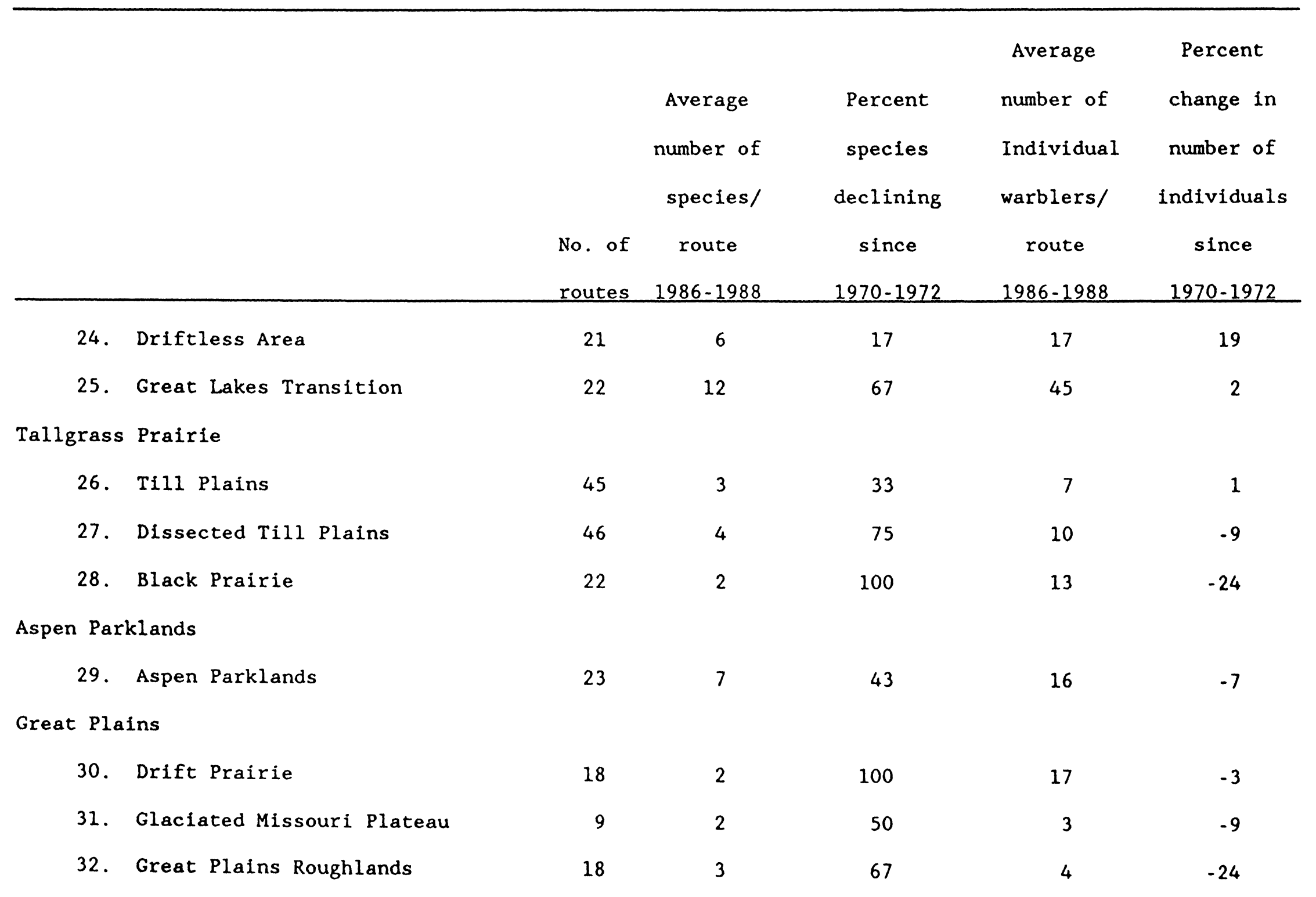


Table 1 (continued).

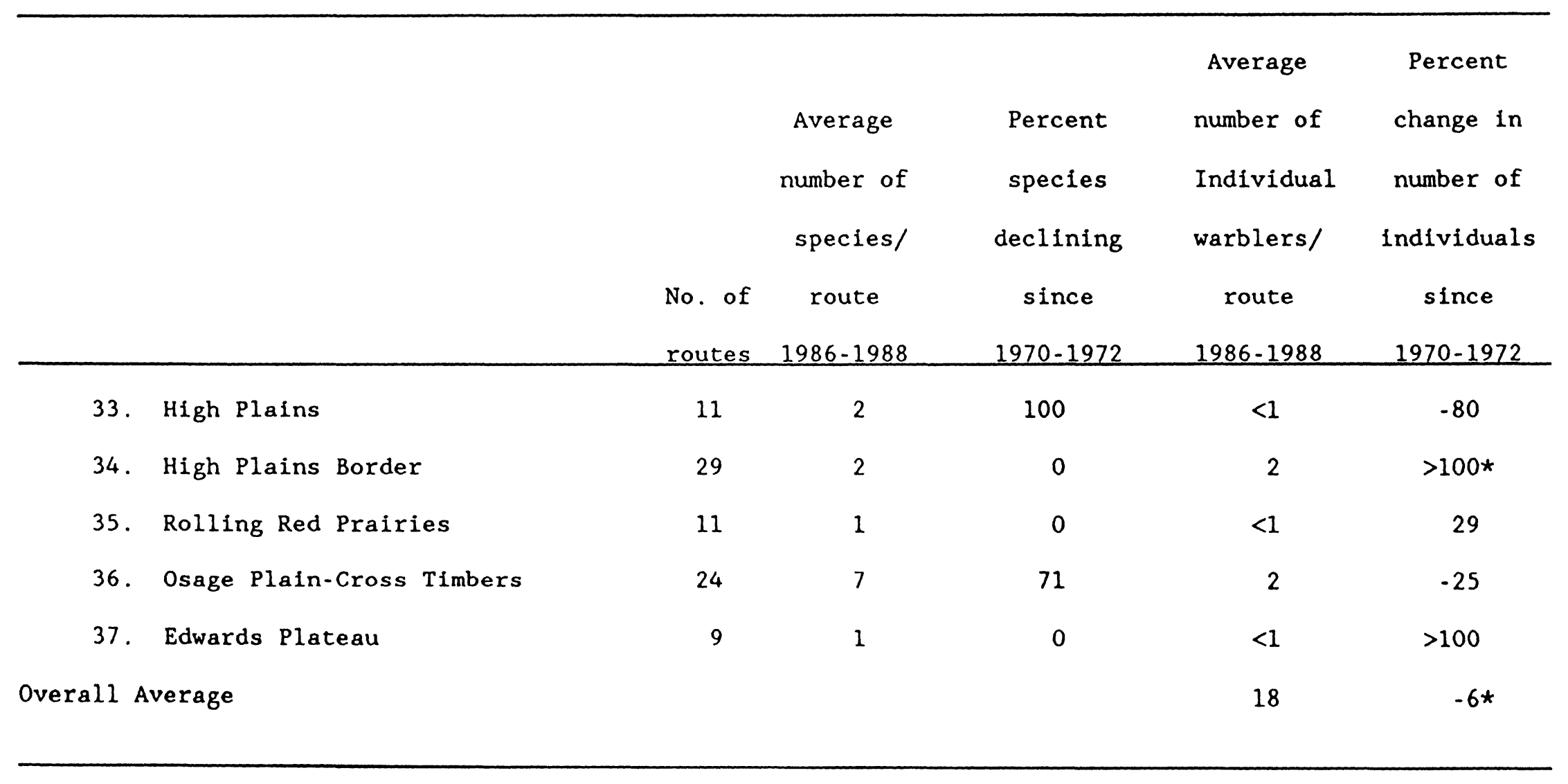


Table 2. Twenty-six species of warblers, the number of routes and strata included in the analysis, the estimated average number of birds per route on routes on which the species occurred recently (1986-1988), and the percent change since the early part of the BBS period (1970-1972). Estimates are reported for both nonlinear nonparametric route regression (NNRR) and nonlinear semiparametric route regression (NSRR). The difference between the methods is that NSRR includes an adjustment for potential differences among observers in their ability to detect birds. Asterisks indicate statistically significant percent changes at $\alpha-<0.05$ based on $z$-tests.

\begin{tabular}{|c|c|c|c|c|c|c|c|}
\hline & & \multirow{2}{*}{$\begin{array}{l}\text { No. of } \\
\text { routes } \\
\text { NSRR } \\
\end{array}$} & \multirow{2}{*}{$\begin{array}{l}\text { No. of } \\
\text { strata } \\
\text { NSRR }\end{array}$} & \multicolumn{2}{|c|}{$\begin{array}{l}\text { Birds/route } \\
1986-1988 \\
\end{array}$} & \multicolumn{2}{|c|}{$\begin{array}{l}\text { Percent change } \\
\text { from } 1970-1972 \\
\text { to } 1986-1988\end{array}$} \\
\hline & & & & NNRR & NSRR & NNRR & NSRR \\
\hline & Cerulean Warbler, ${ }^{\text {w }}$ Dendrolca cerulea & 95 & 8 & 0.2 & 0.1 & $-47 \star$ & $-71 *$ \\
\hline & Prairie Warbler, $\mathbf{s}$ Dendroica discolor & 320 & 16 & 0.8 & 0.8 & $-41 *$ & $-45 *$ \\
\hline & Canada Warbler, ${ }^{\mathrm{w}}$ Wilsonia canadensis & 144 & 6 & 0.7 & 0.6 & $-37 *$ & $-50 *$ \\
\hline & Yellow-breasted Chat, $\mathbf{s}$ Icteria virens & 406 & 21 & 2.8 & 3.0 & $-27 *$ & $-24 \star$ \\
\hline & Golden-winged Warbler, ${ }^{s}$ Vermivora chrysoptera & 105 & 8 & 0.2 & 0.2 & -27 & -39 \\
\hline & American Redstart, ${ }^{w}$ Setophaga ruticilla & 429 & 21 & 1.2 & 1.1 & -10 & $-32 \star$ \\
\hline
\end{tabular}




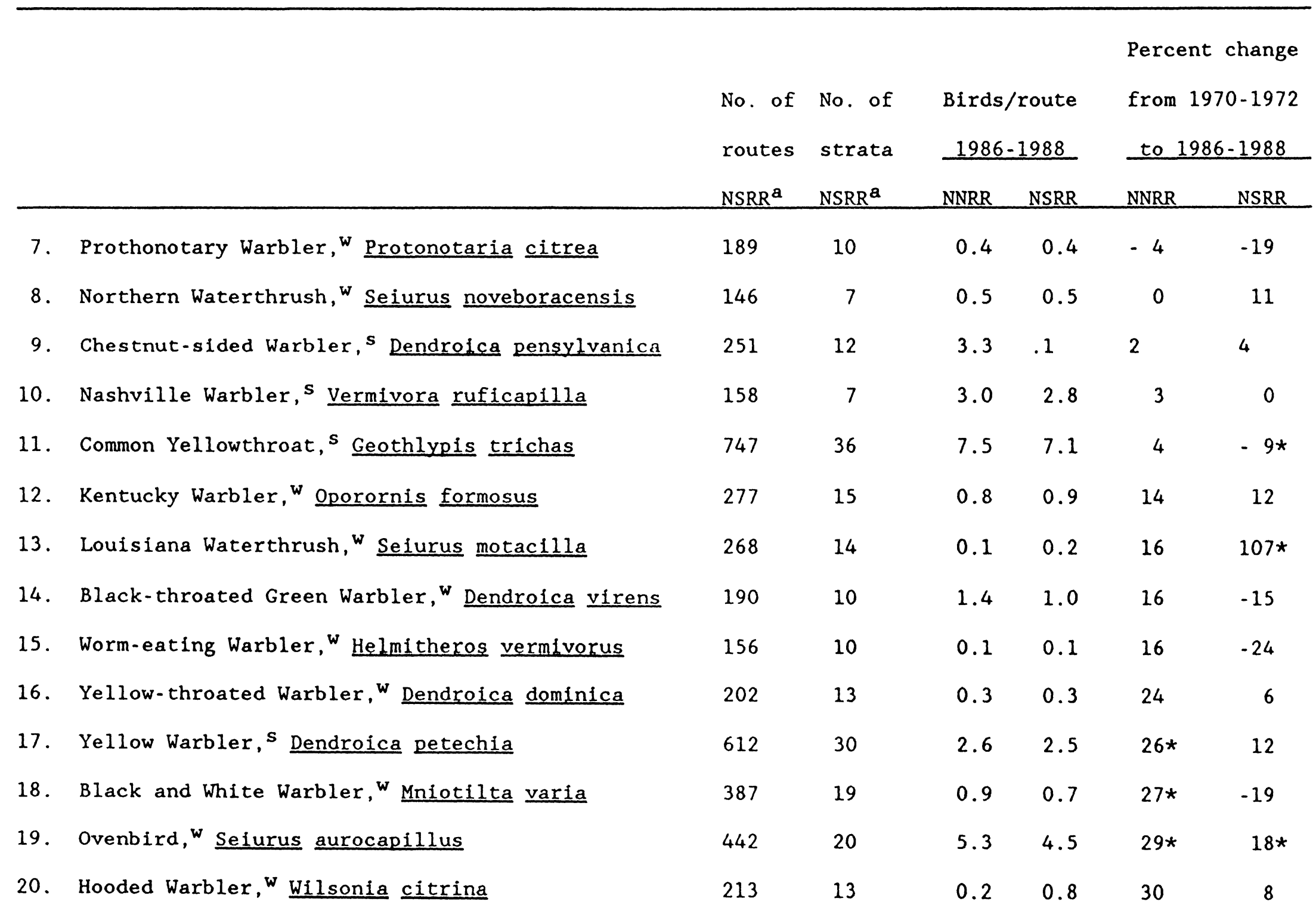




\begin{tabular}{|c|c|c|c|c|c|c|c|}
\hline & & $\begin{array}{l}\text { No. of } \\
\text { routes }\end{array}$ & $\begin{array}{l}\text { No. of } \\
\text { strata }\end{array}$ & $\begin{array}{l}\text { Birds } \\
1986 \\
\end{array}$ & $\begin{array}{l}\text { route } \\
1988 \\
\end{array}$ & $\begin{array}{l}\text { Perce } \\
\text { from } \\
\text { to } 1\end{array}$ & $\begin{array}{l}\text { change } \\
0-1972 \\
-1988 \\
\end{array}$ \\
\hline & & $\mathrm{NSRR}^{\mathrm{a}}$ & NSRR $^{a}$ & NNRR & NSRR & NNRR & NSRR \\
\hline 21. & Northern Parula, w Parula americana & 320 & 19 & 0.9 & 0.8 & $34 \star$ & 17 \\
\hline 22. & Magnolia Warbler, ${ }^{w}$ Dendroica magnolia & 150 & 6 & 2.7 & 2.4 & $35 *$ & $41 *$ \\
\hline 23. & Blackburnian Warbler, ${ }^{w}$ Dendroica fusca & 153 & 7 & 0.7 & 0.6 & $36 *$ & 11 \\
\hline 24. & Black-throated Blue Warbler, W & & & & & & \\
\hline & Dendroica caerulescens & 128 & 7 & 0.4 & 0.2 & $46 *$ & -9 \\
\hline 25. & Mourning Warbler, ${ }^{s}$ Oporornis philadelphia & 157 & 7 & 1.7 & 1.7 & $51 *$ & $102 \star$ \\
\hline 26. & Blue-winged Warbler, $\mathbf{s}$ Vermivora pinus & 208 & 12 & 0.2 & 0.2 & $61 *$ & 38 \\
\hline & Median \& change & & & & & +168 & +28 \\
\hline & $\begin{array}{l}\text { Nesting in woodland or forest } \\
\text { Nesting in open, successional, }\end{array}$ & & & & & +208 & +128 \\
\hline & or scrub habitat & & & & & +38 & +38 \\
\hline
\end{tabular}

${ }^{a}$ Numbers for NNRR are the same or slightly higher.

${ }^{w}$ Nesting in woodland or forest.

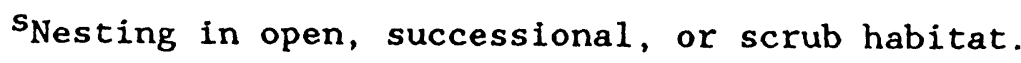


Table 3. Physiographic strata where the estimated probability of a decline in a hypothetical species between $1970-1972$ and 1986-1988 was higher than 0.7 (a) or lower than 0.3 (b) on the basis of a probit-normal model applied to a matrix of increases and decreases for each species estimated by either NNRR or NSRR. Strata with high values have estimated unusual proportions of species that decreased, those with low values have unusual proportions of species that increased. If there were no geographic variation, all strata would have probabilities equal to the overall average.

$\begin{array}{cc}\text { Estimated probability } & \text { Estimated probability } \\ \text { of decline for an } & \text { of decline for an } \\ \text { average species, NSRR } & \text { average species, NNRR }\end{array}$

a. Strata with an unusually high

proportion of species decreasing

Adirondack Mountains

Cumberland Plateau

Blue Ridge Mountains

Ouachita Mountains

Ridge and Valley

Southern Piedmont

b. Strata with an unusually high

proportion of species increasing

St. Lawrence River Plain

Great Lakes Plain

Spruce Hardwoods and Boreal Forest 


\section{FIGURE LEGENDS}

Fig. 1. Breeding Bird Survey routes in eastern and central North America used in the analysis.

Fig. 2. Overall trend in the number of individual warblers for eastern and central North America (a) and for the four regions that have the most individuals (b). The graphs are based on the average numbers of birds on all routes for each stratum, including routes on which the species was not recorded. They give an index to the density of warblers for the areas indicated.

Fig. 3. The recent (1986-1988) abundance of the Blue-winged Warbler by physiographic strata as estimated with NSRR for routes on which the species occurred (a) and estimated changes in the number of birds per route since early in the BBS period (1970-1972) (b). The categories of change are balanced evenly to enable the reader to make comparisons .

Fig. 4. Nonlinear population trends in the Blue-winged Warbler for the three physiographic strata where it is most abundant. Values that were smoothed were averages for all routes in a stratum, including those on which the species was not recorded. In the 1980's there was a sharp decline in the Ohio Hills, but populations in the Allegheny Plateau and Southern New England continued to increase.

Fig. 5. The recent (1986-1988) abundance of the Ovenbird by physiographic strata as estimated with NSRR for routes on which the species occurred (a) and estimated changes in the number of birds per route since early in the BBS period (1970-1972). The categories of change are balanced evenly to help the reader make comparisons. 
Fig. 6. Nonlinear population trends in the Ovenbird in the 11 strata where it is most abundant. Note the general increases, which are most pronounced in Northern New England and the Great Lakes Transition in the 1980's, as well as the declines in the Adirondack Mountains and the Blue Ridge Mountains.

Fig. 7. Thirty-seven physiographic strata in this analysis (see Table 1 for their names) with three categories for the estimated probability of decline for an average warbler species as determined by nonlinear nonparametric route regression (NNRR) and a probit-normal model (see text and Appendix for methods of analysis).

Fig. 8. Physiographic strata as in Fig. 7 with three categories for the estimated probability of decline for an average species as determined by nonlinear semiparametric route regression (NSRR) and a probit. normal model. 


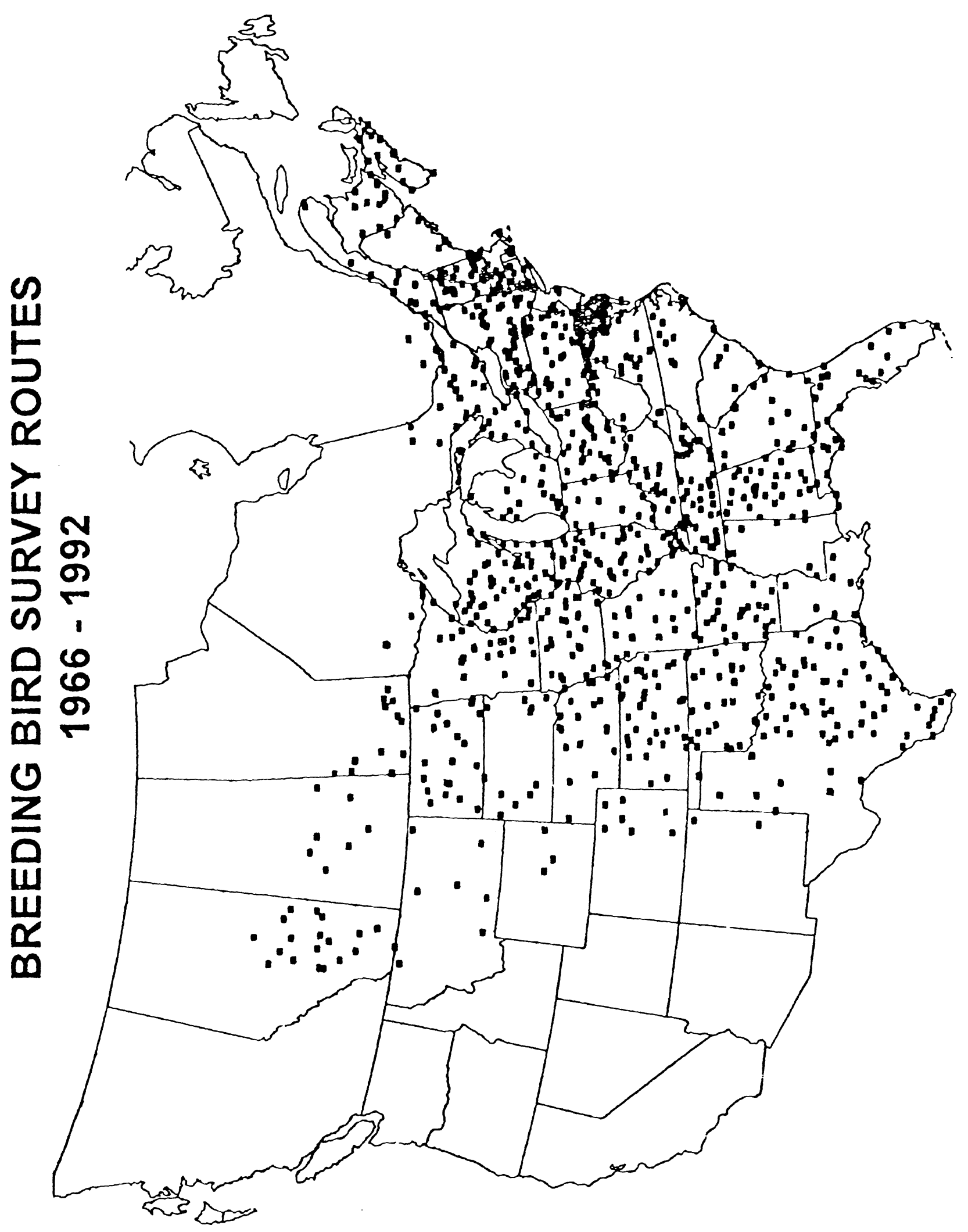




\section{SPECIES OF WARBLERS}

a.

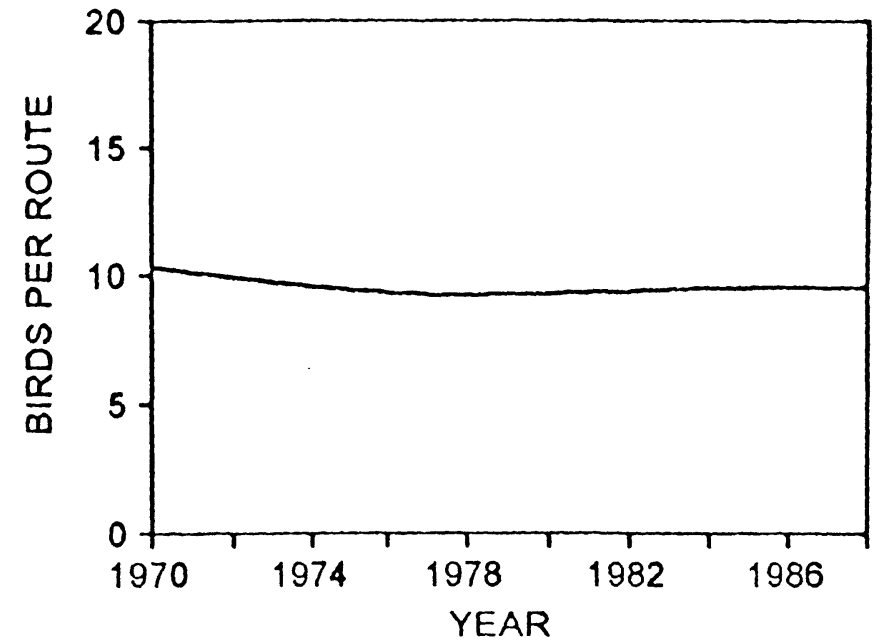

b.

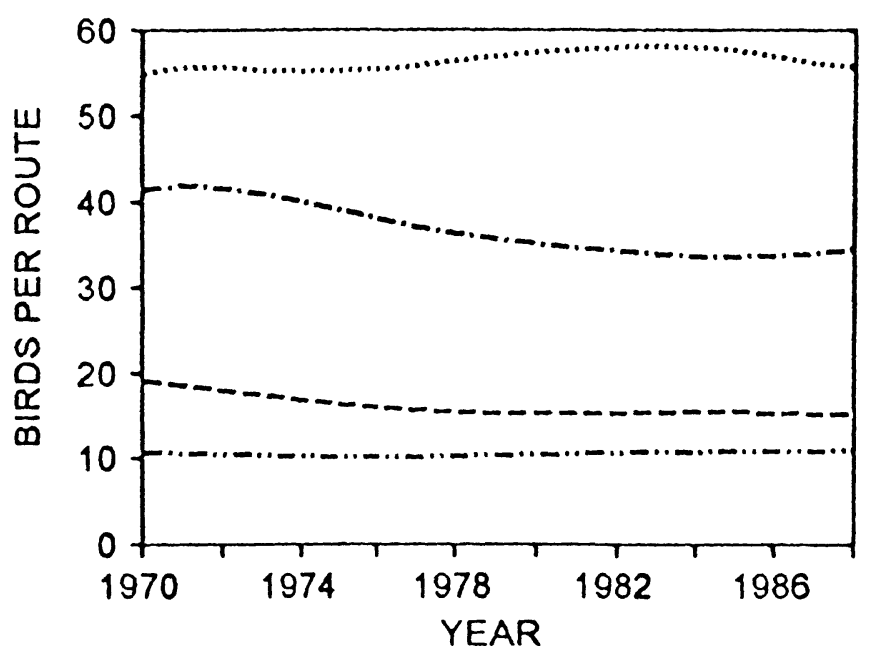

...... Spruce-Hardwood \& Boreal Forest

-.- Appalachian Mountains

- - Eastern Foothills

-...- Eastern Coastal Plain's. 
BLUE-WINGED WARBLER

a.

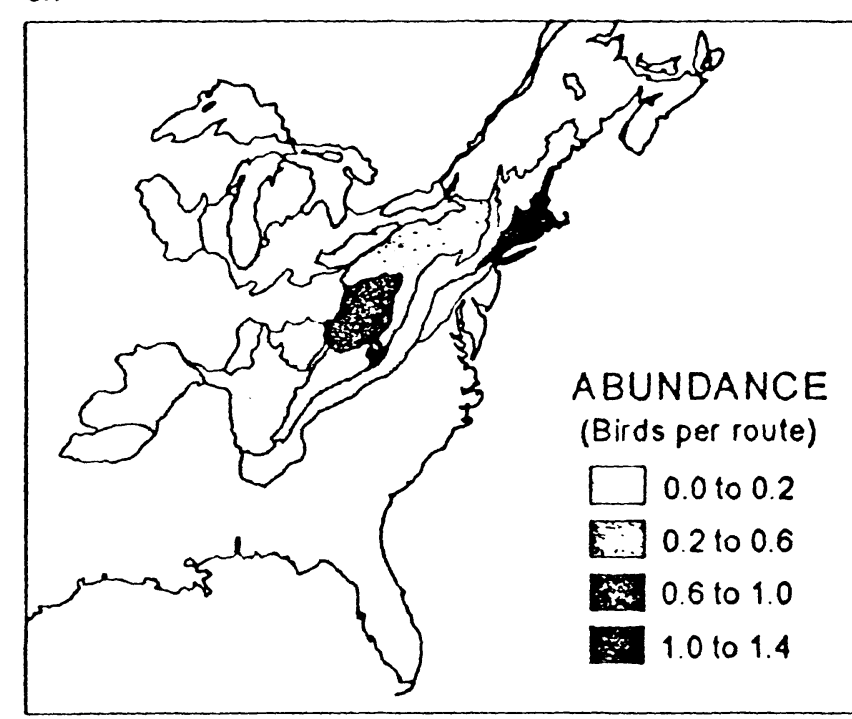

b.

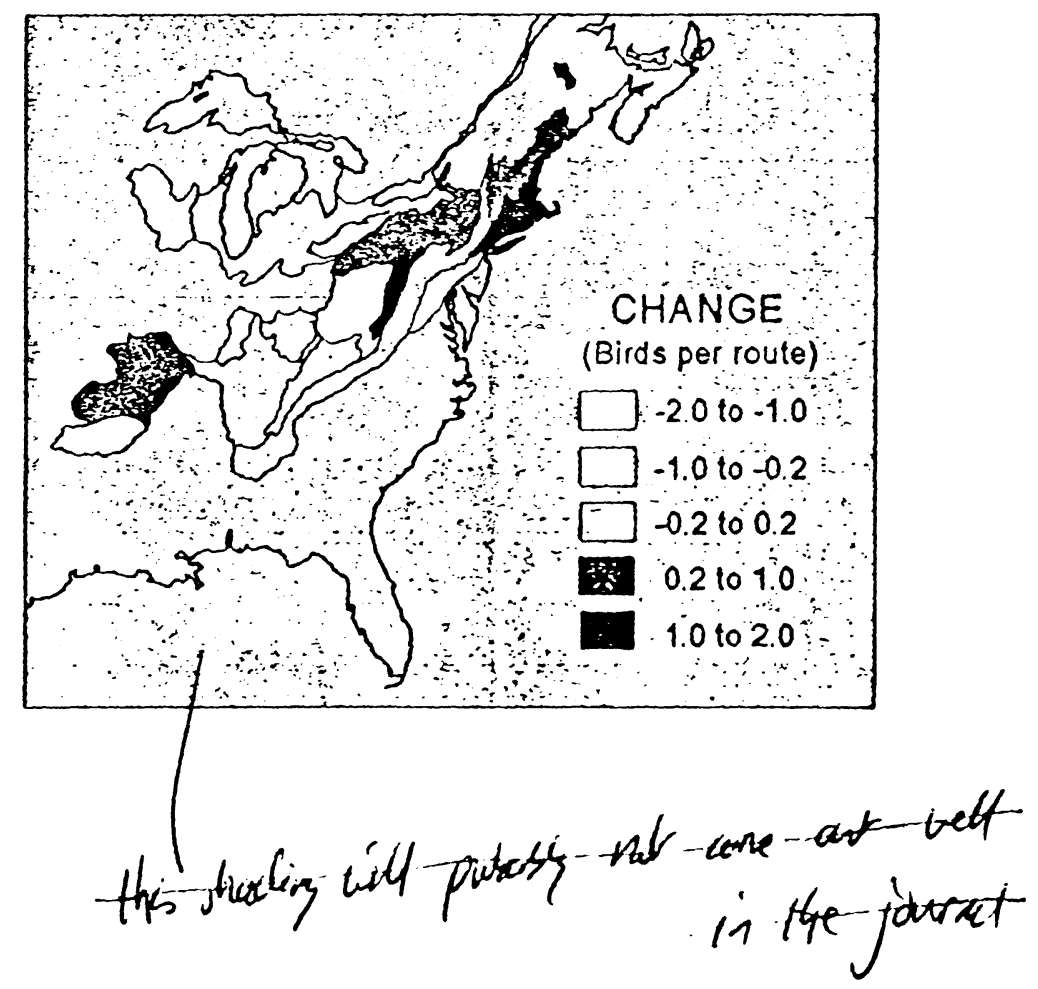




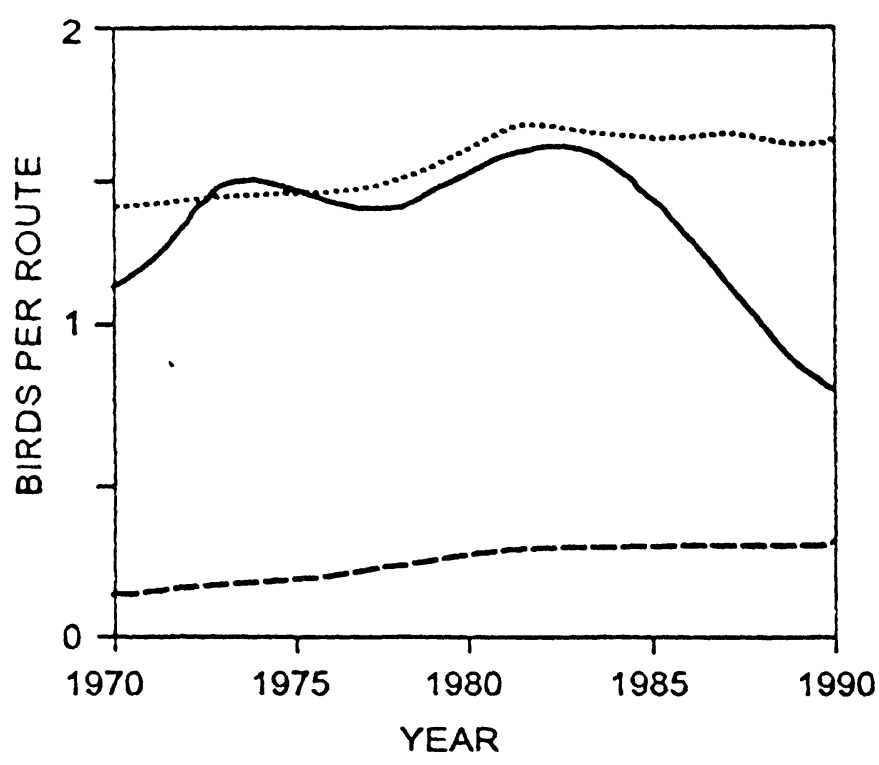

$$
\begin{gathered}
\text {........ Southern New England \& } \\
\text { Glaciated Coastal Plain } \\
\text { Ohio Hills } \\
\text {--. Allegheny Plateau }
\end{gathered}
$$


OVENBIRD

a.

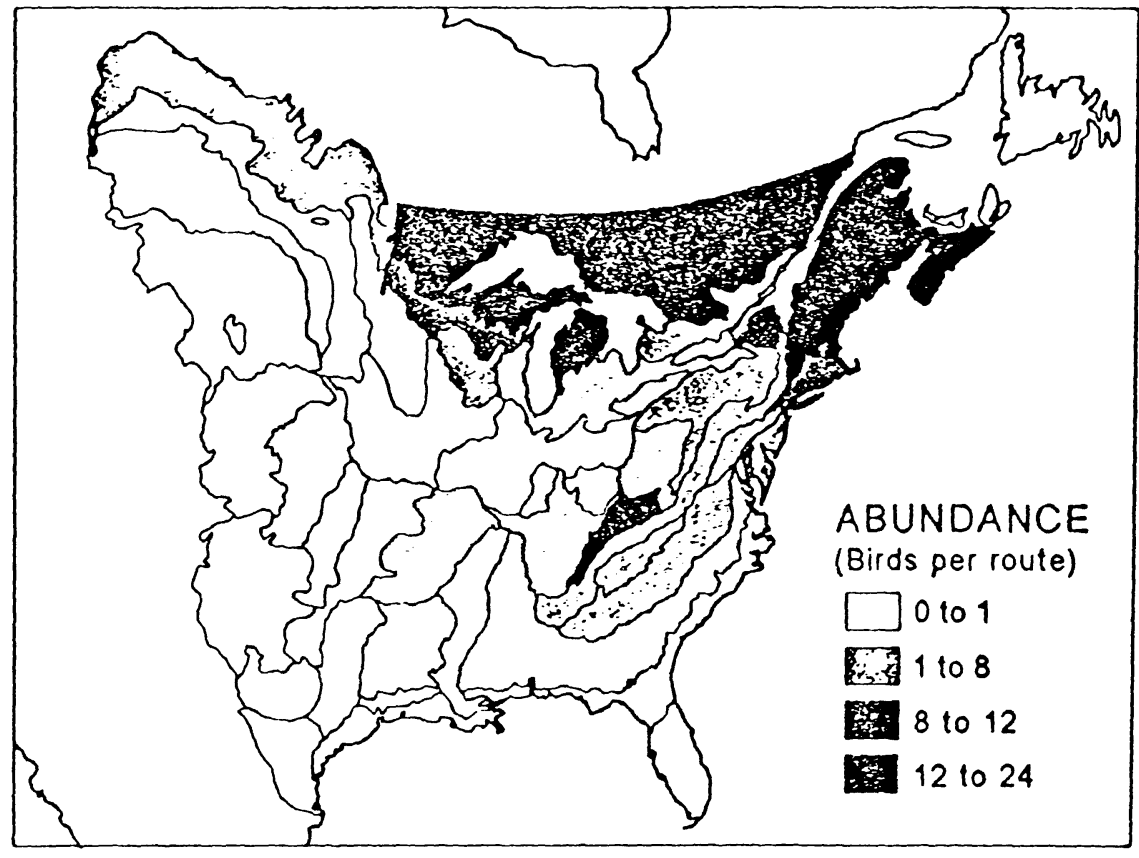

b.

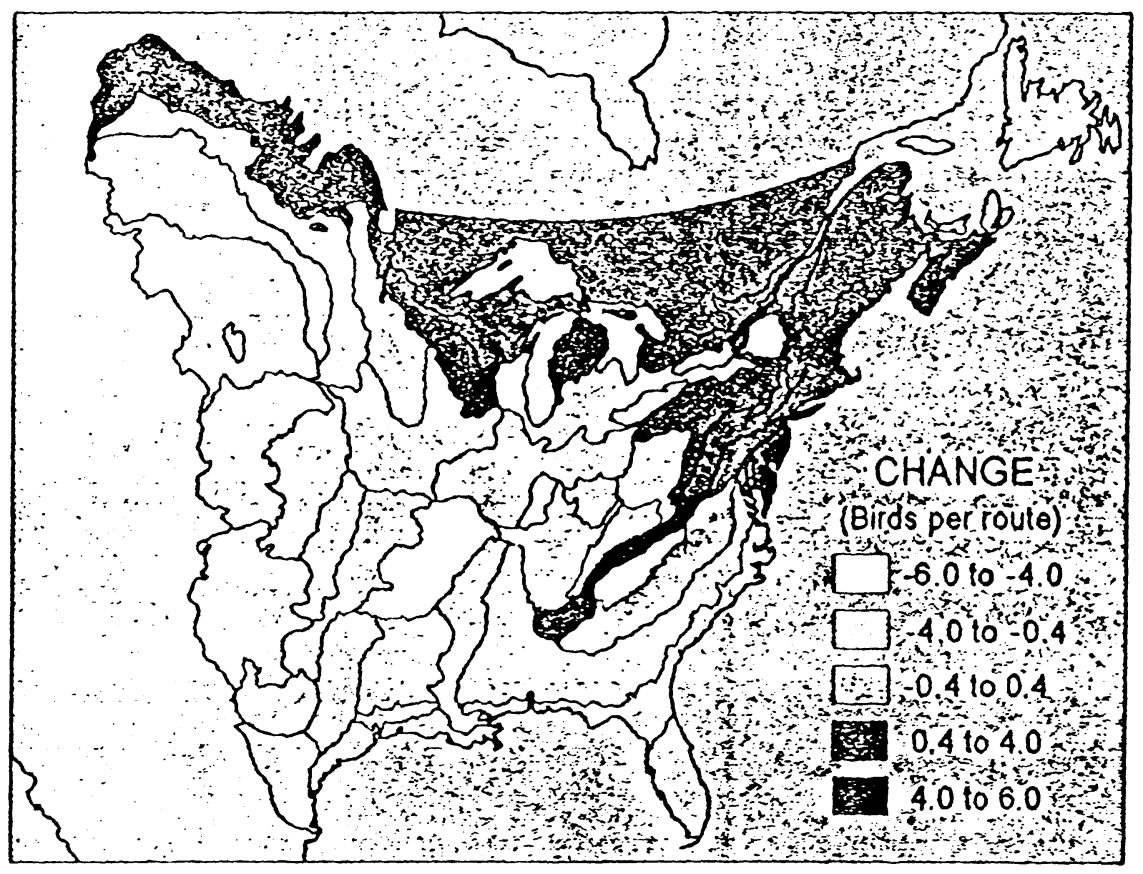



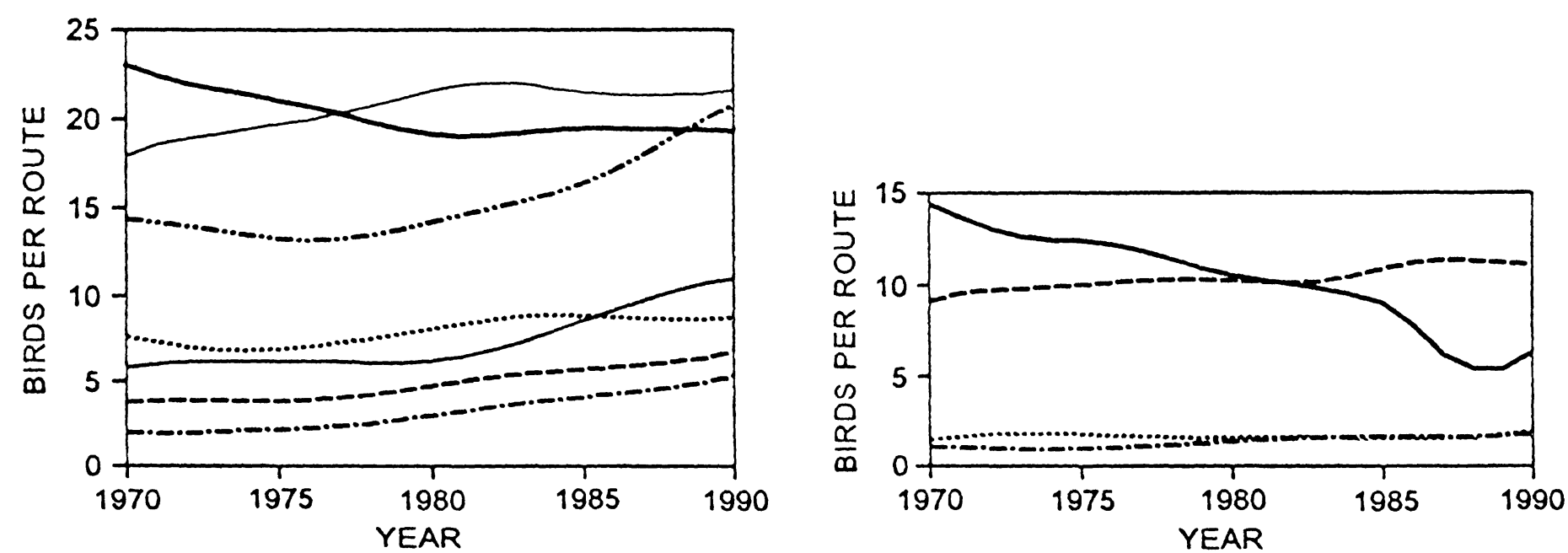

- Spruce-Hardwood
\& Boreal Forest
- Adirondack Mountains
-..- Northern New England
..... Southern New England
- Great Lakes Transition
--- Allegheny Plateau
-.-. St. Lawrence River Plain

- Blue Ridge Mountains

--- Cumberland Plateau

...... Northem Piedmont

-.- Ridge and Valley 


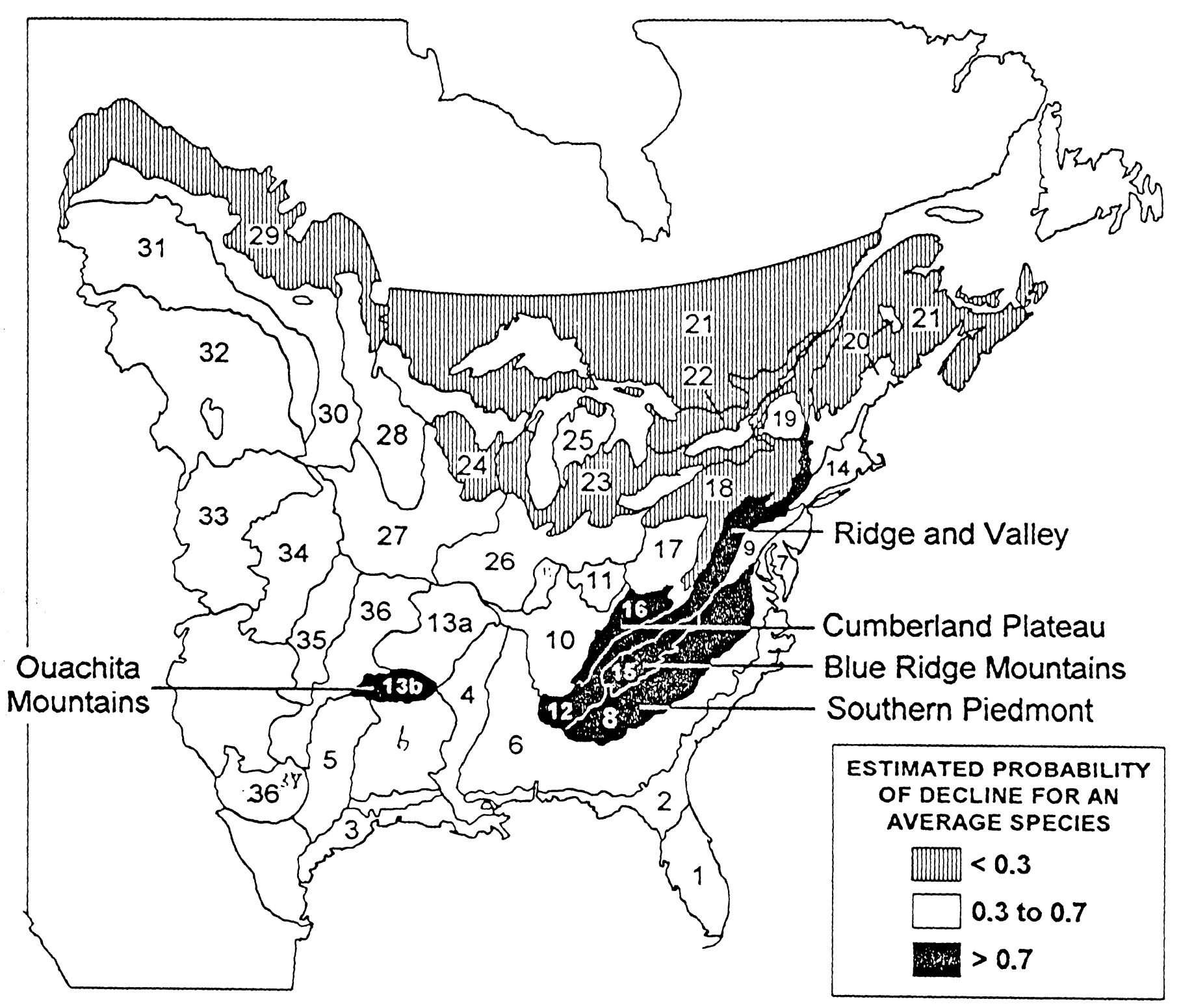




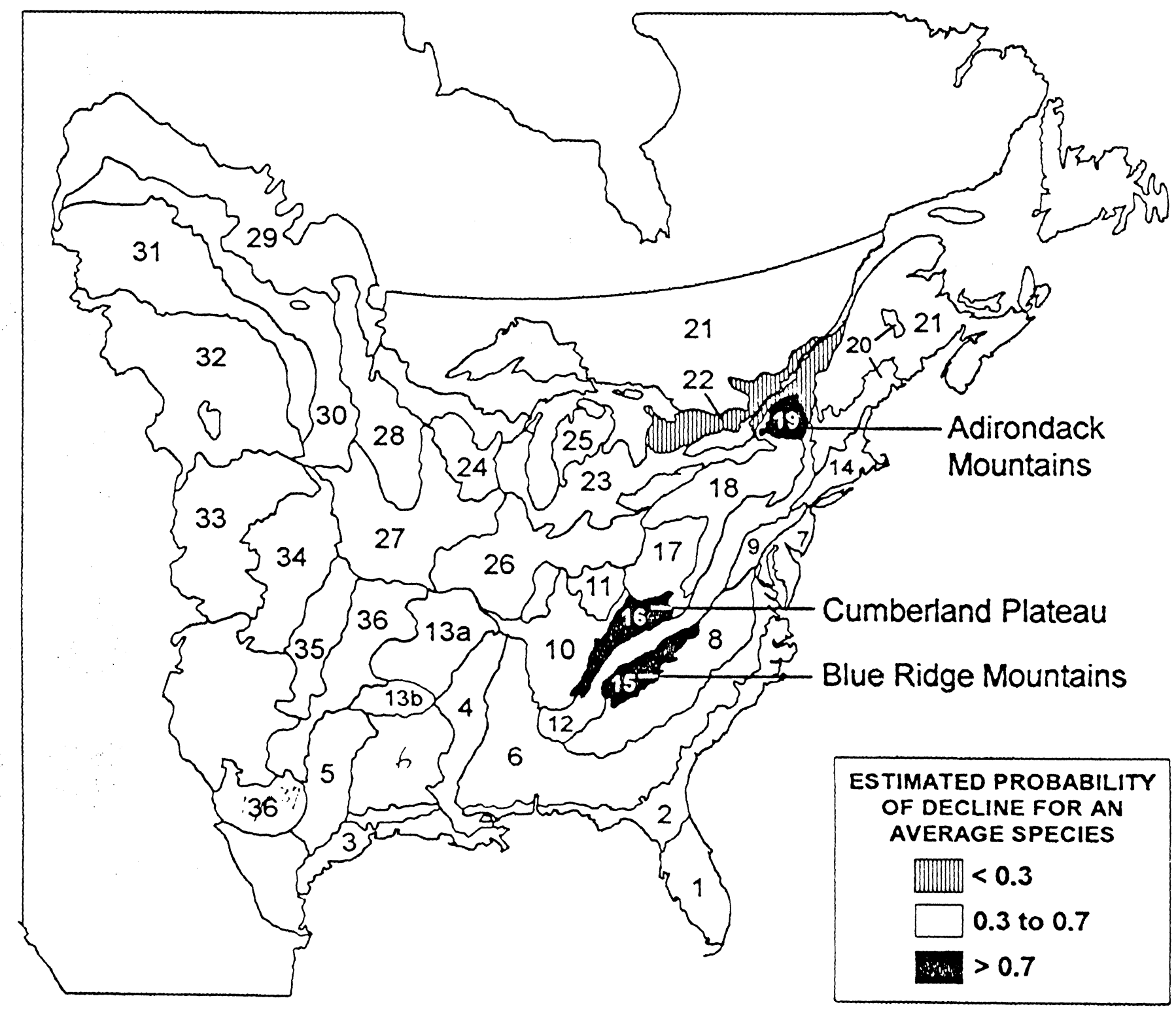

